\title{
EVALUATION OF THE STRENGTH PROPERTIES OF GLASS WOOL FIBRE REINFORCED CONCRETE
}

\author{
By \\ ${ }^{1}$ OLUTOGE, F.A. and ${ }^{2}$ OGUNDEJI, O.D. \\ ${ }^{1 \& 2}$ Department of Civil Engineering, \\ University of Ibadan, Ibadan. \\ Nigeria.
}

\begin{abstract}
Concrete, as a material has low tensile strength, limited ductility and little resistance to cracking. Several attempts have been made by researchers across the globe to improve these properties through the addition of fibres, such as steel, glass, polypropylene etc. in concrete. In the present investigation, Glass Wool Fibres (GWF) was added to concrete in percentages, varying from 0.00 to $1.05 \%$ by weight of concrete, and its effects on strength properties of the concrete produced investigated.
\end{abstract}

Twenty-Four Cubes $(100 \times 100 \times 100 \mathrm{~mm})$, Sixteen cylinders $(100 \times 200 \mathrm{~mm})$ and sixteen prisms $(100 \times 100 \times 500 \mathrm{~mm})$ were cast and cured for 7 and 28 days respectively after which they were subjected to compressive, split-tensile and flexural strength tests.

The results showed that inclusion of GWF in concrete has little effect on the concrete compressive strength. There was however considerable improvement in the split-tensile and flexural strength of concrete. Glass wool fibre reinforced concrete with $0.35 \%$ fibre content gave the optimum value of $10.0 \%$ and $16.2 \%$ increase in split tensile and flexural strength respectively compared to plain concrete (control). Increase in fibre content beyond $0.35 \%$ gave comparatively little or no increase in concrete strength properties.

It is recommended that the use of GWF in concrete be limited to about $0.35 \%$ by weight in order to optimize the enhancement of strength properties of concrete.

Keywords: Glass wool fibre, concrete, Compressive strength, Split-tensile test, Flexural strength.

\subsection{Introduction}

Concrete is the most widely used manmade construction material in the world, and is second only to water as the most utilized substance on the planet. The strength, durability and other characteristics of concrete depend upon the properties of its ingredients, on the proportions of mix, the method of compaction and other controls during placing, compaction and curing. Concrete, as the most widely used construction material, has several desirable properties like high compressive strength, stiffness, and sometimes durability under usual environmental factors. At the same time concrete is brittle and weak in tension. Plain concrete has two deficiencies- low tensile strength and a low strain at fracture. These shortcomings are generally overcome by reinforcing the concrete (Komol Chawla, 2013). Apart from the two deficiencies afore mentioned, concrete also has undesirable attributes. Plain concrete is relatively heavy, easily influenced by weather and fire, susceptible to cracks due to shrinkage, creep, and temperature changes.

Fibre Reinforced Concrete (FRC) is defined as a composite material essentially consisting of conventional concrete or mortar reinforced by the random dispersal of short, discontinuous, and discrete fine fibres of specific geometry (Hamid et al, 2001). Fibre-reinforced concrete (FRC) is concrete containing fibrous material which increases its structural integrity. It contains short discrete fibres that are uniformly distributed and randomly oriented. Fibres include steel fibres, glass fibres, synthetic fibres and natural fibres each of which lend varying properties to the concrete. In addition, the character of fibre-reinforced concrete changes with varying concretes, fibre materials, geometries, distribution, orientation, and densities (Li V. et al, 2008). Materials used in fibre reinforcing including acrylic, asbestos, 
cotton, glass, nylon, polyester, polyethylene, polypropylene, rayon, rock wool and steel. Of these, acid resistive glass fibres and steel fibres have received the most attention.

Fibre reinforced concrete is distinguished from concrete reinforced with rods (reinforcement bars) by the following characteristics:

- Fibres are short and closely spaced unlike reinforcing bars which are continuous.

- Fibres are distributed through given cross section while reinforcement bars are only placed where required.

- Fibres give a smaller reinforcement ratio i.e. area of reinforcement: area of concrete when compared to reinforcement bars.

Several types of fibres have been used to reinforce concrete. The choice of type varies from synthetic organic materials such as polypropylene or carbon, synthetic inorganic such as steel or glass, natural organic such as cellulose to natural inorganic such as asbestos. Fibres can control cracking more effectively due to their tendency to be more closely spaced than conventional reinforcing steel bars. Hamid et al (2012) highlighted that fibre used as the concrete reinforcement is not a substitute for conventional steel bars. Fibres and steel bars have different roles to play in advanced concrete technology, and there are many applications in which both fibres and continuous reinforcing steel bars should be used.

Glass wool, which is one product called "fibreglass" today, was invented in 1938 by Russell Games Slayter of Owens-Corning. It is an insulating material made from fibres of glass arranged using a binder into a texture similar to wool. The process traps many small pockets of air between the glass, and these small air pockets result in the thermal insulation properties. Glass wool is produced in rolls or in slabs, with different thermal and mechanical properties. It may also be produced as a material that can be sprayed or applied in place, on the surface to be insulated.

It is manufactured after the mixture of natural sand and recycled glass at $1,450{ }^{\circ} \mathrm{C}$, the glass that is produced is converted into fibres. It is typically produced in a method similar to making cotton candy, forced through a fine mesh by centripetal force, cooling on contact with the air. It was established by Gowri et al (2013) that the presence of glass wool fibre in concrete increases the concrete strength properties and also serves as cracks arrestor.

\subsection{Materials and Method}

\section{Materials}

All the materials used in the study were locally sourced and include the following:

1. Ordinary Portland Cement

2. Fine aggregate

3. Coarse aggregate

4. Water

5. Fibreglass (Glass wool fibre)

\section{Material Properties}

\section{Cement}

In the present investigation, ordinary Portland cement (Elephant brand) conforming to BS 12, (1996) was used as it is readily available in local market.

\section{Fine Aggregate}

Locally available river sand within the University community was used in the investigation. The fine aggregate particle sizes ranges from $0.10-5.0 \mathrm{~mm}$ in diameter which conformed to the requirements of BS 882 (1982).

\section{Coarse Aggregate}

Machine crushed well graded angular granite aggregate of nominal size not greater than $12 \mathrm{~mm}$ from local source was used for the project work.

\section{Water}

Locally available portable water, free from any visible impurities and conforming to BS 3148 (1989) was used in the preparation of the concrete mix. Generally, the requirement of water should be reduced to that required for chemical reaction of hydrated cement, as any excess water would end up in formation of undesirable voids in the hardened cement paste or concrete.

\section{Fibreglass (Glass Wool Fibre)}

The glass wool fibre used was locally sourced having modulus of elasticity of $55 \mathrm{GPa}$, filament diameter (D) $8 \mu \mathrm{m}$, specific gravity 2.68 , length (L) $14 \mathrm{~mm}$ and aspect ratio (L/D) of 
Proc. of the Third Intl. Conf. Advances in Civil, Structural and Mechanical Engineering- CSM 2015

Copyright (C) Institute of Research Engineers and Doctors, USA .All rights reserved.

ISBN: 978-1-63248-062-0 doi: 10.15224/ 978-1-63248-062-0-68

1750. The details of the properties of glass wool fibre used as obtained from Man-made vitreous fibres: nomenclature, chemical and physical properties. Stamford, CT, Thermal Insulation Manufacturers' Association are provided in table 2.1 below:

Table 2.1 Properties of the Glass Wool Fibre

\begin{tabular}{|c|c|}
\hline Fibre : & Glass Wool \\
\hline Specific gravity : & 2.60 \\
\hline Modulus of elasticity (GPa) : & 55 \\
\hline Length (mm) : & 14 \\
\hline Diameter (micron) : & 8 \\
\hline Aspect ratio : & 1750 \\
\hline Effect of temperature : & Non-combustible \\
\hline
\end{tabular}



\section{Plate 2.1: Glass Wool Fibre}

\section{Methods}

The experimental investigations were conducted at the Faculty of Technology of the University, using cube, cylinder, and beam specimens to evaluate compressive strength, splitting tensile strength, and flexural strength respectively. The glass wool fibres of $0.35 \%$, $0.70 \%$ and $1.05 \%$ by volume fraction of concrete were used. Plain concrete specimens for all studies were cast as well. These plain concrete specimens served as the control experiment.

Mix Design
Grade 20 concrete was designed and a water-cement ratio of 0.5 were maintained for all the mixes. Glass wool fibres of $0.35 \%$, $0.70 \%$ and $1.05 \%$ were added separately in each batch while a plain concrete mix of glass wool fibre content $(0 \%)$ batch was used as the control experiment. The equivalent quantity by weight of each ingredient of the concrete mix per cubic meter is as shown in table 2.2 below:

Table 2.2 Materials Required Per Cubic Meter

\begin{tabular}{|c|c|c|c|c|}
\hline $\begin{array}{c}\text { Cement } \\
\text { (kg) }\end{array}$ & $\begin{array}{c}\text { Fine } \\
\text { Aggregate } \\
(\mathrm{kg})\end{array}$ & $\begin{array}{c}\text { Coarse } \\
\text { Aggregate } \\
(\mathrm{kg})\end{array}$ & $\begin{array}{c}\text { Water : } \\
\text { Cement } \\
\text { (water } \\
\text { in ltr) }\end{array}$ & $\begin{array}{c}\text { Glass } \\
\text { Wool } \\
\text { Fibre } \\
(\mathrm{kg})\end{array}$ \\
\hline 47 & 94 & 187 & $0.5(24)$ & 1.710 \\
\hline
\end{tabular}

\section{Test Specimens}

A total number of 56 specimens were cast and tested. These comprises 24 cube specimens of sizes 100x100x100mm, 16 cylinder specimens of diameter $100 \mathrm{~mm}$ and height $200 \mathrm{~mm}$, and 16 beams of sizes 100x100x500mm. The specimens were of two sets. The first sets comprised 6 cubes, 4 cylinders, and 4 beams with $0 \%$ fibres present in the concrete mix. The second sets comprised 18 cubes, 12 cylinders and 12 beams with varying fibre percentages.

There were four different mixes altogether. The first mix (for control experiment) was without fibres while the remaining three mixes were with fibres of percentages $0.35 \%, 0.70 \%$, and $1.05 \%$ for consistency. Each mix consist 6 cubes, 4 cylinders, and 4 beams. The concrete was mixed by hand due to small quantity of each mix with the fibres being added mid way into the mixing process. The concrete with and without fibres mix was then poured into the various specimen moulds using hand trowel, in three layers and each layer tamped with tamping rod 25 times in order to assure a dense mix and a uniform distribution of the fibres. After 24 hours, the specimens were demoulded and cured in water for 7 days and 28 days. 


\section{Testing of Specimens Slump Test}

The concrete slump test is an empirical test that measures the workability of fresh concrete. The workability of fresh concrete is the ease at which concrete can be poured and compacted i.e. flow. The test is performed to check the consistency of the freshly prepared concrete. The slump test was performed on all the mixes immediately after mixing using slump cone, slump plate, tamping rod, and ruler. The values of the true slump obtained are provided in Table 3.1

\section{Compressive Strength Test}

One of the most important and useful properties of concrete is the compressive strength as shown in plate 2. In most structural applications, concrete is used primarily to resist compressive stress. The compression test was conducted on the 24 cube specimens cured for 7 and 28 days. The cube specimens were removed from the moist storage few minutes before testing, and weighed. The top and bottom bearing plates of the ADR Touch 1500 Compression Testing Machine with Digital Readout were wiped and cleaned before the placement of the specimen. The tests were carried out at a uniform stress rate, after the specimen was centered in the testing machine. The loading rate was $6.0000 \mathrm{KN} / \mathrm{sec}$. and was continued till the specimen reached its ultimate load. The ultimate load divided by the cross sectional area of the specimen is equal to the ultimate compressive strength. Both the ultimate load in $\mathrm{KN}$ and the compressive strength in $\mathrm{MPa}$ of the specimen were displayed on the testing machine display unit. The values obtained are provided in Table 3.2 and 3.3.

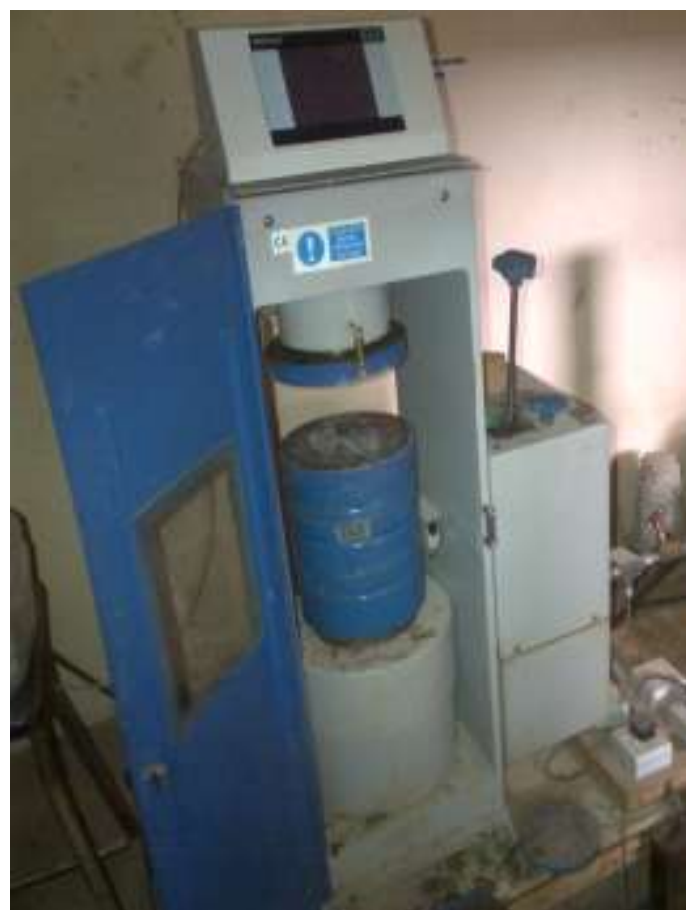

Plate 2.2 ADR Touch Compressive Testing

Machine

\section{Split Tensile Strength Test}

The splitting test is well known as indirect test used for determining the tensile strength of concrete. The determination of tensile strength of concrete is necessary to determine the load at which the concrete members may crack. In this test, a compressive force is applied to a concrete specimen in such a way that the specimen fails due to tensile stresses developed in the specimen. The split test was conducted on the 16 cylinder specimens cured for 7 and 28 days. The test cylinders were removed from the moist storage few minutes before testing. The top and bottom bearing plates of the ADR Touch 1500 Compression Testing Machine with Digital Readout were wiped and cleaned before the placement of the specimen. The tests were carried out at a uniform stress rate, after the concrete cylinder was placed with its axis horizontal between the compressive plates of the testing machine. The loading rate was $0.9400 \mathrm{KN} / \mathrm{sec}$. and was continued till the specimen reached its ultimate load. Both the ultimate load in $\mathrm{KN}$ and the tensile strength in MPa of the specimen were displayed on the testing machine display unit. The values obtained are provided in Table 3.5 and Table 3.6. 


\section{Flexural Strength Test}

Flexural strength, also known as modulus of rupture is the ability of the specimen to resist deformation under load. The flexural strength test was conducted on the 16 beam specimens cured for 7 and 28 days. The test cylinders were removed from the moist storage few minutes before testing. The flexural test was performed according to BS EN 12390 Part 5 (2000) using the centre-point loading method. According to the standard procedure, the beams were placed so that the reference direction of loading was perpendicular to the direction of casting. Deformation was measured at the centre point of the beams. The loading rate was 0.2000 $\mathrm{KN} / \mathrm{sec}$. and was continued till the specimen reached its ultimate load. Both the ultimate load in $\mathrm{KN}$ and the flexural strength in MPa of the specimen were displayed on the testing machine display unit. The values obtained are provided in Table 3.8 and Table 3.9.

\subsection{Results and Discussion}

The concrete slump test was carried out on all the four mixes and the values of true slump obtained are as shown in Table 3.1

Table 3.1: Slump Test Results Carried Out on Freshly Prepared Concrete

\begin{tabular}{|c|c|c|c|}
\hline Mixes & $\begin{array}{c}\text { GWF } \\
\text { Content } \\
(\%)\end{array}$ & $\begin{array}{c}\text { Slump } \\
(\mathrm{mm})\end{array}$ & $\begin{array}{c}\text { Average } \\
\text { Slump } \\
(\mathrm{mm})\end{array}$ \\
\hline \multirow[t]{2}{*}{ First } & 0.00 & 75 & \multirow[b]{2}{*}{72} \\
\hline & & 68 & \\
\hline \multirow[t]{2}{*}{ Second } & 0.35 & 66 & \multirow[b]{2}{*}{64} \\
\hline & & 62 & \\
\hline \multirow[t]{2}{*}{ Third } & 0.70 & 53 & \multirow[b]{2}{*}{57} \\
\hline & & 60 & \\
\hline \multirow[t]{2}{*}{ Fourth } & 1.05 & 54 & \multirow[b]{2}{*}{51} \\
\hline & & 48 & \\
\hline
\end{tabular}

Two slump values were measured for each mix so as to obtain the average slump value. The average slump values, as shown in Table 3.1, ranges from $51 \mathrm{~mm}$ to $72 \mathrm{~mm}$. It is evident that the inclusion of GWF in the fresh concrete reduced the slump values in the increasing order of the GWF content. For $0.00 \%$ GWF content, the average slump was $72 \mathrm{~mm}$, for $0.35 \%$ content, the average slump was $64 \mathrm{~mm}$, for $0.7 \%$ content, it was $57 \mathrm{~mm}$, and for $1.05 \%$ content, the average slump was $51 \mathrm{~mm}$. Thus, all the measured slumps were true slumps.

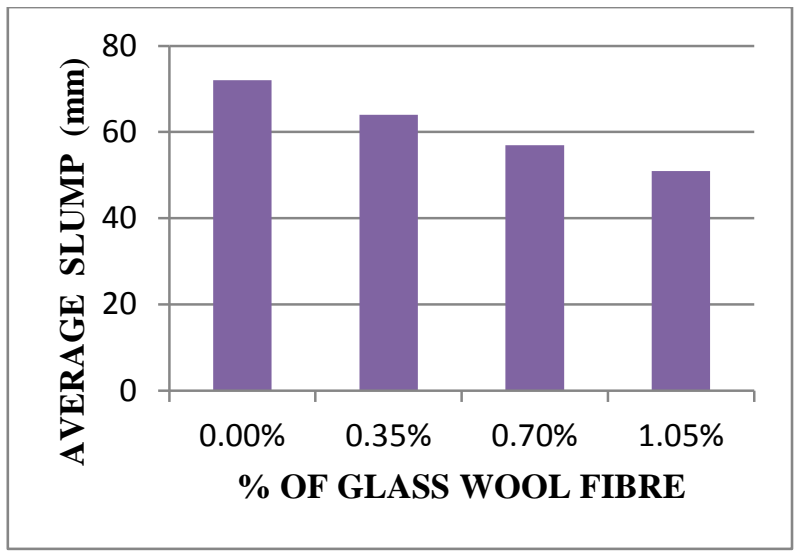

Fig. 3.1 Concrete Slump Test Result

\section{Compressive Strength Test Results}

The various results of the compressive strength test carried out on the cube specimens at each age of test are provided here. The compressive strength values of cube specimens at age 7 days are shown in Table 3.2 while those at age 28 days are shown in Table 3.3 as displayed on the display unit of the ADR Touch 1500 Compression Testing Machine with Digital Readout. 
Proc. of the Third Intl. Conf. Advances in Civil, Structural and Mechanical Engineering- CSM 2015 Copyright (C) Institute of Research Engineers and Doctors, USA .All rights reserved.

ISBN: 978-1-63248-062-0 doi: 10.15224/ 978-1-63248-062-0-68

Table 3.2: Compressive Strength Test Results of Cube Specimens at Age 7 Days

\begin{tabular}{|c|c|c|c|c|c|c|}
\hline Mixes & $\begin{array}{c}\text { GWF Content } \\
(\%)\end{array}$ & Sample ID & $\begin{array}{c}\text { Weight } \\
\text { (Kg) }\end{array}$ & $\begin{array}{l}\text { Load } \\
(\mathrm{KN})\end{array}$ & $\begin{array}{c}\text { Compressive } \\
\text { Strength (MPa) }\end{array}$ & $\begin{array}{l}\text { Average } \\
\text { (MPa) }\end{array}$ \\
\hline \multirow{3}{*}{ First } & \multirow{3}{*}{0.00} & P70 & 2.80 & 171.2 & 17.12 & \multirow{3}{*}{16.32} \\
\hline & & P70 & 3.00 & 163.2 & 16.32 & \\
\hline & & $\mathrm{P} 70$ & 2.80 & 147.1 & 14.71 & \\
\hline \multirow{3}{*}{ Second } & \multirow{3}{*}{0.35} & F73 & 2.70 & 199.5 & 19.95 & \multirow{3}{*}{19.07} \\
\hline & & F73 & 2.90 & 172.2 & 17.22 & \\
\hline & & F73 & 2.60 & 200.4 & 20.04 & \\
\hline \multirow{3}{*}{ Third } & \multirow{3}{*}{0.70} & F77 & 3.00 & 154.3 & 15.43 & \multirow{3}{*}{14.55} \\
\hline & & F77 & 2.80 & 137.5 & 13.75 & \\
\hline & & F77 & 2.80 & 144.8 & 14.48 & \\
\hline \multirow{3}{*}{ Fourth } & \multirow{3}{*}{1.05} & F71 & 2.60 & 103.5 & 10.35 & \multirow{3}{*}{9.68} \\
\hline & & F71 & 2.70 & 91.00 & 9.10 & \\
\hline & & F71 & 2.80 & 95.90 & 9.59 & \\
\hline
\end{tabular}

Table 3.3: Compressive Strength Test Results of Cube Specimens at Age 28 Days

\begin{tabular}{|c|c|c|c|c|c|c|}
\hline Mixes & $\begin{array}{c}\text { GWF Content } \\
(\%)\end{array}$ & Sample ID & $\begin{array}{c}\text { Weight } \\
\text { (Kg) }\end{array}$ & Load (KN) & $\begin{array}{c}\text { Compressive } \\
\text { Strength (MPa) }\end{array}$ & $\begin{array}{c}\text { Average } \\
\text { (MPa) }\end{array}$ \\
\hline \multirow{3}{*}{ First } & \multirow{3}{*}{0.00} & $\mathrm{P} 20$ & 2.80 & 243.8 & 24.38 & \multirow{3}{*}{24.55} \\
\hline & & $\mathrm{P} 20$ & 2.70 & 253.4 & 25.34 & \\
\hline & & $\mathrm{P} 20$ & 2.60 & 239.2 & 23.92 & \\
\hline \multirow{3}{*}{ Second } & \multirow{3}{*}{0.35} & F23 & 2.80 & 229.1 & 25.91 & \multirow{3}{*}{25.89} \\
\hline & & F23 & 3.20 & 252.8 & 25.28 & \\
\hline & & F23 & 2.80 & 264.9 & 26.49 & \\
\hline \multirow{3}{*}{ Third } & \multirow{3}{*}{0.70} & F27 & 2.70 & 166.5 & 16.65 & \multirow{3}{*}{18.43} \\
\hline & & F27 & 3.20 & 187.9 & 18.79 & \\
\hline & & F27 & 3.10 & 198.5 & 19.85 & \\
\hline \multirow{3}{*}{ Fourth } & \multirow{3}{*}{1.05} & F21 & 2.80 & 115.8 & 11.58 & \multirow{3}{*}{12.27} \\
\hline & & F21 & 2.60 & 117.6 & 11.76 & \\
\hline & & F21 & 3.20 & 134.7 & 13.47 & \\
\hline
\end{tabular}


Proc. of the Third Intl. Conf. Advances in Civil, Structural and Mechanical Engineering- CSM 2015 Copyright $\odot$ Institute of Research Engineers and Doctors, USA .All rights reserved.

ISBN: 978-1-63248-062-0 doi: 10.15224/ 978-1-63248-062-0-68

Table 3.4: Summary of Compressive Strength of Cube Specimens

\begin{tabular}{|c|c|c|c|}
\hline \multirow{2}{*}{ Mixes } & GWF Content & \multicolumn{2}{|c|}{ Average Compressive Strength (N/mm $\left.\mathbf{2}^{\mathbf{}}\right)$} \\
\cline { 3 - 4 } & $(\%)$ & $\mathbf{7}$ Days & $\mathbf{2 8}$ Days \\
\hline First & 0.00 & 16.32 & 24.55 \\
\hline Second & 0.35 & 19.07 & 25.89 \\
\hline Third & 0.70 & 14.55 & 18.43 \\
\hline Fourth & 1.05 & 9.68 & 12.27 \\
\hline
\end{tabular}

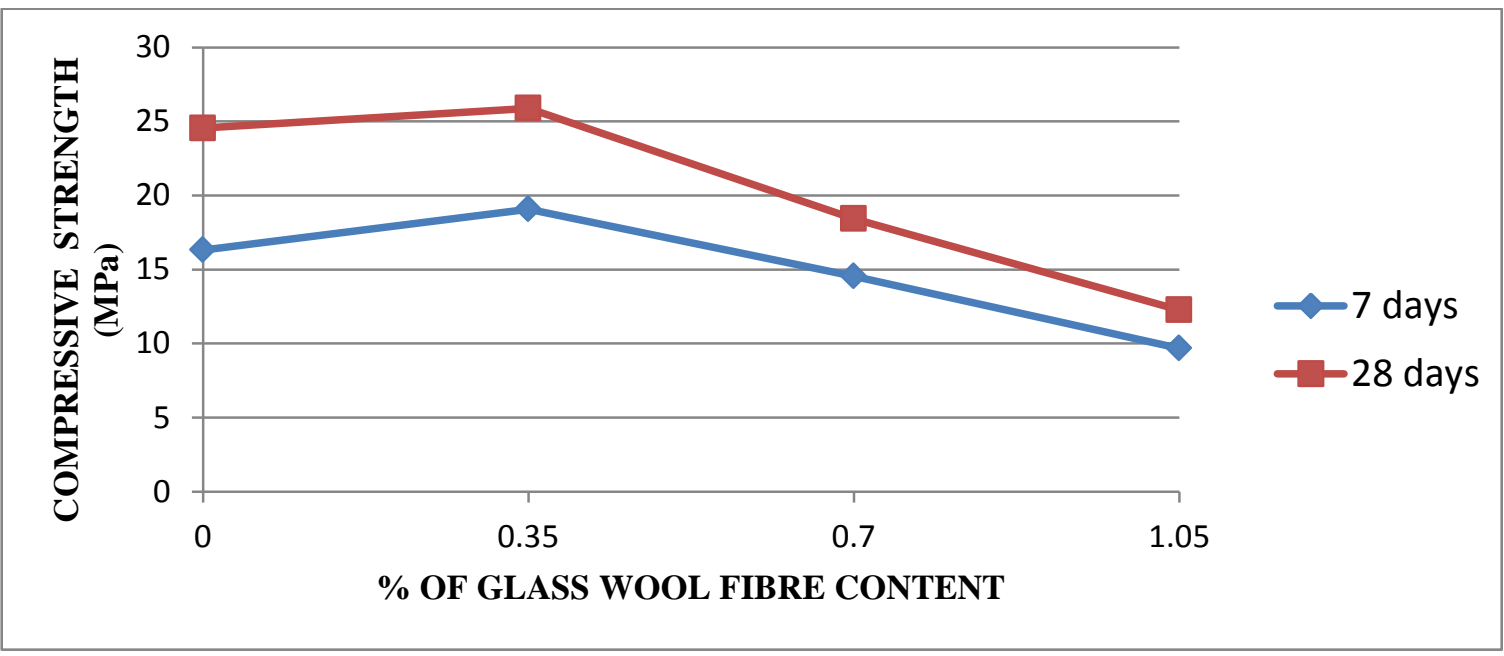

Fig. 3.2 Compressive Strength vs \% of Glass Wool Fibre content

The Table 3.4 and Fig. 3.2 show the variations in compressive strength of concrete at different ages and varying Glass Wool Fibre (GWF) contents. At age 7 days, the compressive strength value for plain concrete (i.e. control concrete mix) is observed to be $16.32 \mathrm{~N} / \mathrm{mm}^{2}$ while the compressive strength value for glass wool fibrereinforced concrete is $19.07 \mathrm{~N} / \mathrm{mm}^{2}$ for $0.35 \%$ of GWF content; $14.55 \mathrm{~N} / \mathrm{mm}^{2}$ for $0.70 \%$; and $9.68 \mathrm{~N} / \mathrm{mm}^{2}$ for $1.05 \%$. Also, at age 28 days, the compressive strength value for plain concrete is observed to be $24.55 \mathrm{~N} / \mathrm{mm}^{2}$ while the compressive strength value for glass wool fibrereinforced concrete is $25.89 \mathrm{~N} / \mathrm{mm}^{2}$ for $0.35 \%$ of GWF content; $18.43 \mathrm{~N} / \mathrm{mm}^{2}$ for $0.70 \%$; and $12.27 \mathrm{~N} / \mathrm{mm}^{2}$ for $1.05 \%$. Hence, there is $16.85 \%$ and $5.46 \%$ increase in compressive strength with
$0.35 \%$ GWF content at age 7 and 28 days respectively.

However, a significant decrease in compressive strength is observed with increased GWF contents from $0.70 \%$ to $1.05 \%$. This suggests that increase in volume of GWF in concrete has little effect on the compressive strength of concrete, and only up to a certain percentage after which further addition of GWF may result in reduced compressive strength.

\section{Splitting Tensile Strength Test Results}

The results of the splitting tensile strength test carried out on the cylinder specimens at each age of test are provided here. The splitting tensile strength values of cube specimens at age 7 days are shown in Table 3.5 while those at age 28 
Proc. of the Third Intl. Conf. Advances in Civil, Structural and Mechanical Engineering- CSM 2015 Copyright (C) Institute of Research Engineers and Doctors, USA .All rights reserved.

ISBN: 978-1-63248-062-0 doi: 10.15224/ 978-1-63248-062-0-68

days are shown in Table 3.6 as displayed on the display unit of the ADR Touch 1500 Compression Testing Machine with Digital Readout.

Table 3.5: Splitting Tensile Strength Test Results of Cylinder Specimens at Age 7 Days

\begin{tabular}{|c|c|c|c|c|c|}
\hline Mixes & $\begin{array}{c}\text { GWF Content } \\
(\%)\end{array}$ & Sample ID & Load (KN) & $\begin{array}{c}\text { Split Tensile } \\
\text { Strength (MPa) }\end{array}$ & $\begin{array}{c}\text { Average } \\
\text { (MPa) }\end{array}$ \\
\hline \multirow[t]{2}{*}{ First } & 0.00 & P70 & 56.60 & 1.80 & \multirow[b]{2}{*}{1.70} \\
\hline & & P70 & 49.80 & 1.60 & \\
\hline \multirow[t]{2}{*}{ Second } & 0.35 & F73 & 60.50 & 1.90 & \multirow[b]{2}{*}{1.85} \\
\hline & & F73 & 57.40 & 1.80 & \\
\hline \multirow[t]{2}{*}{ Third } & 0.70 & F77 & 51.70 & 1.60 & \multirow[b]{2}{*}{1.45} \\
\hline & & F77 & 42.60 & 1.30 & \\
\hline \multirow[t]{2}{*}{ Fourth } & 1.05 & F71 & 31.90 & 1.00 & \multirow[b]{2}{*}{1.10} \\
\hline & & F71 & 38.90 & 1.20 & \\
\hline
\end{tabular}

Table 3.6: Splitting Tensile Strength Test Results of Cylinder Specimens at Age 28 Days

\begin{tabular}{|c|c|c|c|c|c|}
\hline Mixes & $\begin{array}{c}\text { GWF Content } \\
(\%)\end{array}$ & Sample ID & Load (KN) & $\begin{array}{c}\text { Split Tensile } \\
\text { Strength (MPa) }\end{array}$ & $\begin{array}{c}\text { Average } \\
\text { (MPa) }\end{array}$ \\
\hline \multirow[t]{2}{*}{ First } & 0.00 & P20 & 65.60 & 2.00 & \multirow[b]{2}{*}{2.00} \\
\hline & & $\mathrm{P} 20$ & 64.80 & 2.00 & \\
\hline \multirow[t]{2}{*}{ Second } & 0.35 & F23 & 71.10 & 2.30 & \multirow[b]{2}{*}{2.20} \\
\hline & & F23 & 68.10 & 2.10 & \\
\hline \multirow[t]{2}{*}{ Third } & 0.70 & F27 & 42.10 & 1.30 & \multirow[b]{2}{*}{1.45} \\
\hline & & F27 & 53.30 & 1.60 & \\
\hline \multirow[t]{2}{*}{ Fourth } & 1.05 & F21 & 47.30 & 1.50 & \multirow[b]{2}{*}{1.25} \\
\hline & & F21 & 34.10 & 1.00 & \\
\hline
\end{tabular}


Proc. of the Third Intl. Conf. Advances in Civil, Structural and Mechanical Engineering- CSM 2015 Copyright $\odot$ Institute of Research Engineers and Doctors, USA .All rights reserved.

ISBN: 978-1-63248-062-0 doi: 10.15224/ 978-1-63248-062-0-68

Table 3.7: Summary of Splitting Tensile Strength of Cylinder Specimens

\begin{tabular}{|c|c|c|c|}
\hline \multirow{2}{*}{ Mixes } & GWF Content & \multicolumn{2}{|c|}{ Average Splitting Tensile Strength (N/mm $\left.{ }^{2}\right)$} \\
\cline { 3 - 4 } & $(\%)$ & 7 Days & 28 Days \\
\hline First & 0.00 & 1.70 & 2.00 \\
\hline Second & 0.35 & 1.85 & 2.2 \\
\hline Third & 0.70 & 1.45 & 1.45 \\
\hline Fourth & 1.05 & 1.10 & 1.25 \\
\hline
\end{tabular}

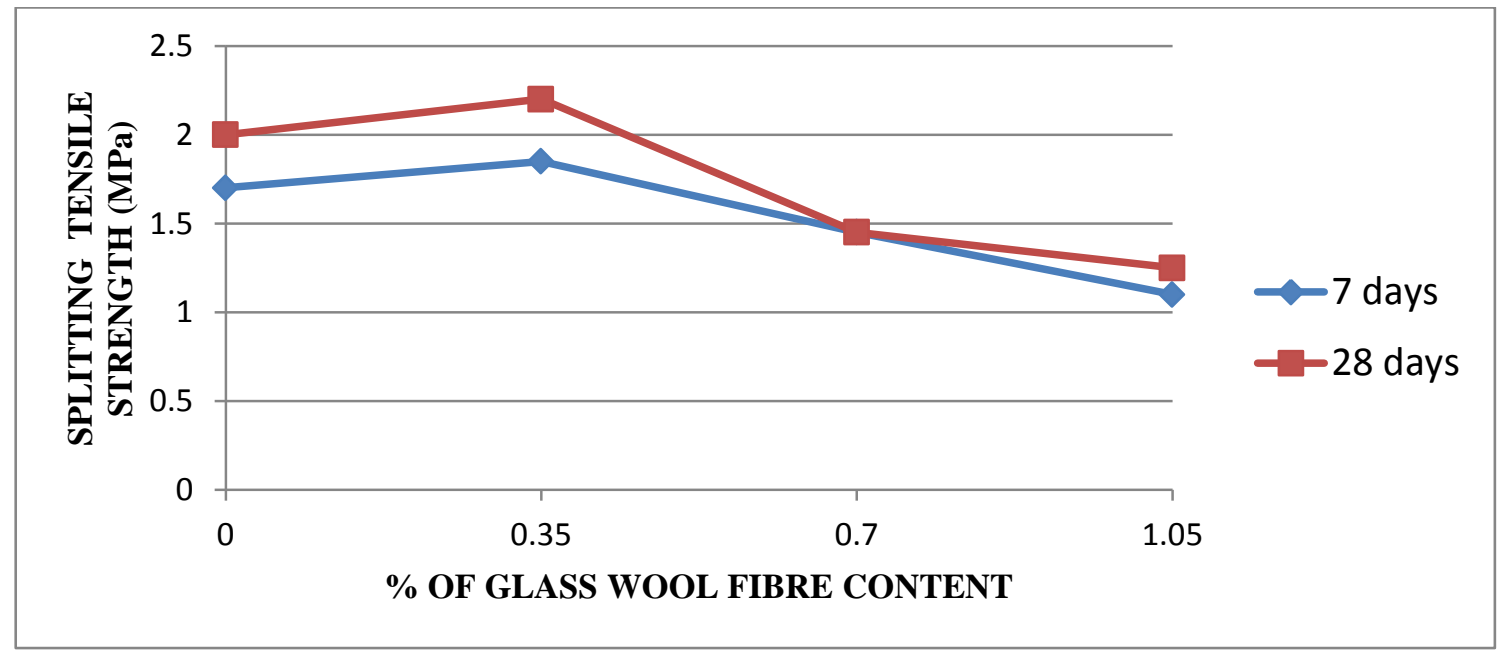

Fig. 3.3 Splitting Tensile Strength vs \% of Glass Wool Fibre content

The variations in splitting tensile strength of concrete at different ages and varying Glass Wool Fibre (GWF) contents are shown in Table 3.7 and Fig. 3.3. At age 7 days, the splitting tensile strength value for plain concrete (i.e. control concrete mix) is observed to be $1.70 \mathrm{~N} / \mathrm{mm}^{2}$ while the splitting tensile strength value for glass wool fibre-reinforced concrete is $1.85 \mathrm{~N} / \mathrm{mm}^{2}$ for $0.35 \%$ of GWF content; $1.45 \mathrm{~N} / \mathrm{mm}^{2}$ for $0.70 \%$; and $1.10 \mathrm{~N} / \mathrm{mm}^{2}$ for $1.05 \%$. Also, at age 28 days, the splitting tensile strength value for plain concrete is observed to be $2.00 \mathrm{~N} / \mathrm{mm}^{2}$ while the splitting tensile strength value for glass wool fibre-reinforced concrete is $2.20 \mathrm{~N} / \mathrm{mm}^{2}$ for $0.35 \%$ of GWF content; $1.45 \mathrm{~N} / \mathrm{mm}^{2}$ for $0.70 \%$; and $1.25 \mathrm{~N} / \mathrm{mm}^{2}$ for
$1.05 \%$. Hence, there is $8.8 \%$ and $10.0 \%$ increase in splitting tensile strength with $0.35 \%$ GWF content at age 7 and 28 days respectively.

It is, however, observed that there is a noticeable decline in splitting tensile strength with increased GWF contents from $0.70 \%$ to $1.05 \%$. Thus, this implies that when volume of GWF in concrete is increased up to a particular percentage, its further addition may result in reduced splitting strength of the concrete.

Flexural Strength Test Results

The results of the flexural strength test on the beam specimens at age 7 days are shown in Table 3.8 while those at age 28 days are shown in Table 3.9 as displayed on the display unit of the ADR Testing Machine with Digital Readout. 
Proc. of the Third Intl. Conf. Advances in Civil, Structural and Mechanical Engineering- CSM 2015 Copyright (C) Institute of Research Engineers and Doctors, USA .All rights reserved.

ISBN: 978-1-63248-062-0 doi: 10.15224/ 978-1-63248-062-0-68

Table 3.8: Flexural Strength Test Results of Beam Specimens at Age 7 Days

\begin{tabular}{|c|c|c|c|c|c|}
\hline Mixes & $\begin{array}{c}\text { GWF Content } \\
(\%)\end{array}$ & Sample ID & Load $(\mathrm{KN})$ & $\begin{array}{c}\text { Flexural Strength } \\
\text { (MPa) }\end{array}$ & $\begin{array}{c}\text { Average } \\
\text { (MPa) }\end{array}$ \\
\hline \multirow[t]{2}{*}{ First } & 0.00 & P70 & 2.80 & 1.10 & \multirow[b]{2}{*}{1.60} \\
\hline & & P70 & 4.50 & 2.1 & \\
\hline \multirow[t]{2}{*}{ Second } & 0.35 & F73 & 5.40 & 2.60 & \multirow[b]{2}{*}{2.50} \\
\hline & & F73 & 5.00 & 2.40 & \\
\hline \multirow[t]{2}{*}{ Third } & 0.70 & F77 & 4.30 & 2.00 & \multirow[b]{2}{*}{2.15} \\
\hline & & F77 & 4.90 & 2.30 & \\
\hline \multirow[t]{2}{*}{ Fourth } & 1.05 & F71 & 3.60 & 1.80 & \multirow[b]{2}{*}{1.70} \\
\hline & & F71 & 3.30 & 1.60 & \\
\hline
\end{tabular}

Table 3.9: Flexural Strength Test Results of Beam Specimens at Age 28 Days

\begin{tabular}{|c|c|c|c|c|c|}
\hline Mixes & $\begin{array}{c}\text { GWF Content } \\
(\%)\end{array}$ & Sample ID & Load (KN) & $\begin{array}{c}\text { Flexural Strength } \\
\text { (MPa) }\end{array}$ & $\begin{array}{c}\text { Average } \\
\text { (MPa) }\end{array}$ \\
\hline \multirow[t]{2}{*}{ First } & 0.00 & P20 & 7.20 & 3.30 & \multirow[b]{2}{*}{3.40} \\
\hline & & P20 & 7.60 & 3.50 & \\
\hline \multirow[t]{2}{*}{ Second } & 0.35 & F23 & 8.20 & 3.90 & \multirow[b]{2}{*}{3.95} \\
\hline & & F23 & 8.40 & 4.00 & \\
\hline \multirow[t]{2}{*}{ Third } & 0.70 & F27 & 7.40 & 3.40 & \multirow[b]{2}{*}{3.55} \\
\hline & & F27 & 7.80 & 3.70 & \\
\hline \multirow[t]{2}{*}{ Fourth } & 1.05 & F21 & 7.20 & 3.30 & \multirow[b]{2}{*}{3.25} \\
\hline & & F21 & 6.90 & 3.20 & \\
\hline
\end{tabular}

Table 3.10: Summary of Flexural Strength of Beam Specimens

\begin{tabular}{|c|c|c|c|}
\hline \multirow{2}{*}{ Mixes } & GWF Content & \multicolumn{2}{|c|}{ Average Flexural Strength (N/mm $\left.{ }^{\mathbf{2}}\right)$} \\
\cline { 2 - 4 } & $(\%)$ & 7 Days & 28 Days \\
\hline First & 0.00 & 1.60 & 3.40 \\
\hline Second & 0.35 & 2.50 & 3.95 \\
\hline Third & 0.70 & 2.15 & 3.25 \\
\hline Fourth & 1.05 & 1.70 & \\
\hline
\end{tabular}




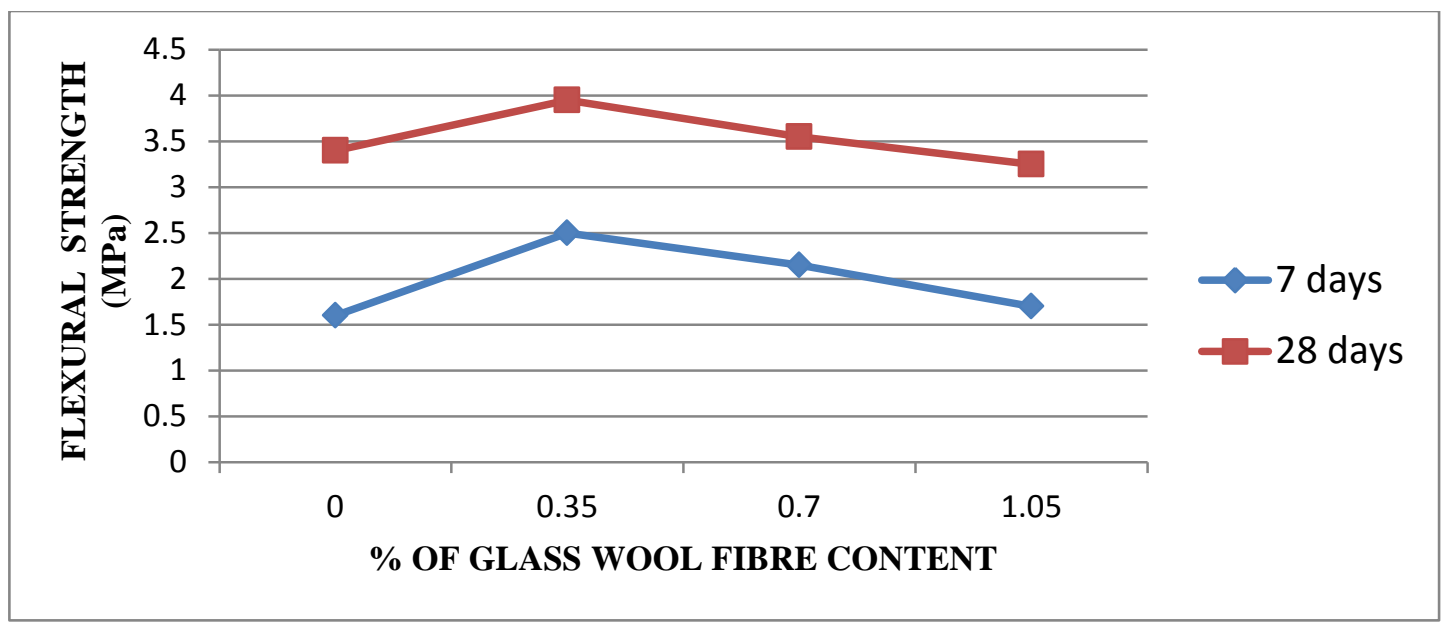

Fig.3.4 Flexural Strength vs \% of Glass Wool Fibre content

The Table 3.10 and Fig. 3.4 show that there is a considerable increase in flexural strength with age. The flexural strength value of the plain concrete is $1.60 \mathrm{~N} / \mathrm{mm}^{2}$, while the flexural strength value of the GWF reinforced concrete is observed to be $2.50 \mathrm{~N} / \mathrm{mm}^{2}, 2.15 \mathrm{~N} / \mathrm{mm}^{2}$, and $1.70 \mathrm{~N} / \mathrm{mm}^{2}$ with GWF contents $0.35 \%, 0.70 \%$, and $1.05 \%$ respectively at age 7 days. Also, the flexural strength value of the plain concrete is $3.40 \mathrm{~N} / \mathrm{mm}^{2}$, while the flexural strength value of the GWF reinforced concrete is observed to be $3.95 \mathrm{~N} / \mathrm{mm}^{2}, 3.55 \mathrm{~N} / \mathrm{mm}^{2}$, and $3.25 \mathrm{~N} / \mathrm{mm}^{2}$ with GWF contents $0.35 \%, 0.70 \%$, and $1.05 \%$ respectively at age 28 days. At 28 days, $16.2 \%$ and $4.4 \%$ increase in flexural strength value are observed in GWF reinforced concrete with $0.35 \%$ and $0.70 \%$ GWF contents respectively, compared to the plain concrete. A keen observation from the results shows that there is an increase in flexural strength value for all mixes with age, and with addition of various percentages of GWF except in $1.05 \%$ GWF content at 28 days where a decline of $4.4 \%$ in flexural strength is observed compared to the plain concrete.

\subsection{Conclusion}

The strength properties of glass wool fibrereinforced concrete (GWFRC) was investigated in this study, and the following conclusions are drawn;

1. The addition of glass wool fibre (GWF) in concrete reduced the workability of the concrete with increasing fibre content.

2. The percentage increase in the strength properties of GWF reinforced concrete increases with the age of concrete.

3. It was also found from the failure pattern of the specimens, that the formation of cracks is more in the case of concrete without fibres than the glass wool fibre reinforced concrete.

4. The inclusion of GWF in concrete had little effect on the compressive strength at 28 days marginally; Increasing Compressive Strength at $0.35 \%$ GWF content and marginally reducing compressive strength at 0.70 and $1.05 \%$ GWF contents.

5. There is $8.8 \%$ and $10.0 \%$ increase in split tensile strength with $0.35 \%$ GWF content at age 7 and 28 days respectively.

6. The incorporation of GWF shows a significant increase in the flexural strength for various percentages of 
GWF. The value increased by $16.2 \%$ with $0.35 \%$ content of GWF.

7. The $0.35 \%$ addition of GWF shows optimum results with respect to all the strength properties evaluated

\subsection{Recommendations}

1. While working with glass wool fibre (GWF), safety precautions such as wearing of hand gloves and use of nose cover are recommended.

2. The use of GWF in concrete should be limited to about $0.35 \%$ volume fraction, as further addition may result in reduced strength properties.

3. Further investigation should be made with GWF contents ranging from $0.35 \%$ down to $0.001 \%$ by weight of concrete.

\section{References}

1. BS EN 12390-5 (2000). Testing Hardened Concrete: Flexural Strength of Test Specimens. British Standard Institution. London, UK.

2. British Standard Code of Practice. BS 3148 , tests for water for making concrete. Standard Institution. London.

3. British Standard Code of Practice (1996). BS 12, Portland cement (ordinary and rapid hardening). British Standard Code of Practice.

4. Ferreira et al (2007), The Use of Glass Fibre-Reinforced Concrete as a Structural Material: Experimental Techniques.

5. Gowri, R, et al (2013), Effect of glass wool fibres on mechanical properties of concrete. International Journal of Engineering Trends and Technology (IJETT) - Vol.4 Issue7- Pp 3045.

6. Hamid et al, (2012), Flexural Behavior of Steel-Fibre-Added-RC (SFARC) Beams with C30 and C50 Classes of Concrete. International Journal of Sustainable Construction Engineering \& Technology, Vol. 3, Issue1.
7. Komal, C, (2013), Studies of Glass Fibre Reinforced Concrete Composites. International Journal of Structural and Civil Engineering Research, Vol. 2, No. 3. Pp 177 - 182.

8. Li, V.; Yang, E.; Li, M. (2008), Field Demonstration of Durable Link Slabs for Jointless Bridge Decks Based on Strain-Hardening Cementitious Composites - Phase 3: Shrinkage Control(PDF), Michigan Department of Transportation.

9. Olutoge, FA, (2013), Evaluation of Residual Strength Properties of Steel Fibre Reinforced Concrete. Journal of Emerging Trends in Engineering and Applied Sciences, vol.4, no.2:p168-172. 